\title{
RETIRED EU MIGRANTS, HEALTHCARE RIGHTS AND EUROPEAN SOCIAL CITIZENSHIP .
}

Article length: 8, 564 (excluding abstract and bibliography)

Key Words: European citizenship, retirement migration, healthcare

This paper is part of a research project funded by the Wellcome Trust under grant number 048853.

\section{Abstract.}

Drawing on a set of 210 qualitative interviews conducted in 6 European countries this paper investigates the citizenship status and experiences of retired EU migrants at both national and European levels. The paper focuses upon the experiences of two types of respondents: 'Retired Migrants' (retired nationals of one EU country who moved on retirement and reside in another EU host state) and 'Returnees,' that is, those migrants who have chosen to return to their country of origin after a period of residence abroad. In particular this paper will attempt to explore three issues:

1. The extent to which retired migrants have access to, and make use of, the public healthcare systems of the countries in which they reside.

2. Retired migrants’ perceptions and experiences of those systems.

3. Whether or not a lack of access to and/or the quality of public healthcare is an important determinant of return migration decisions i.e. moves back to the country of origin. 
By focusing on healthcare the paper combines an analysis of the formal welfare rights available to EU citizens who migrate on retirement (both in terms of their EU rights and their status in the receiving and exporting countries) with qualitative evidence that documents the substantive reality of such rights.

\section{Introduction.}

Article 17 EC (ex Article 8a) formally establishes the concept of 'Citizenship of the Union.' This notion of European citizenship, is however, built around an exclusive ideal of the citizen as a worker. A knock on effect of this approach is the creation of inferior rights for those outside the paid labour market. This paper illustrates that for economically inactive groups, substantive rights (in particular rights to social welfare), are contingent on a number of conditions set out in secondary European legislation. Through an investigation of retired EU migrants' rights in relation to healthcare provision the paper highlights some of the limitations of European citizenship and the strategies such migrants use to ensure that their healthcare needs are met.

To explore these issues further the article is subsequently divided into four parts. Initially, the legal framework that underpins EU citizenship is examined (part two). The inferior (in comparison to migrant workers), right to residence of retired EU migrants is outlined and the negative impact that this has on their status as citizens considered. Part three sketches a brief outline of the methods and sample used in the qualitative study that informs this paper. An examination of the healthcare status and 
experiences of retired EU migrants and how they make use of their rights is then offered in part four. This section of the paper explores the ways in which such migrants seek to meet their healthcare needs in light of their personal circumstances and existing legislation. It serves to highlight two important points. First, the extent to which concerns about accessing healthcare are an important factor in precipitating migratory movements in retirement. Second, the tensions and confusions upon which the emergent notion of European social citizenship is being built. In the conclusion (part five) it is argued that discriminatory elements of European legislation will have to be reconsidered, if, in future, all EU citizens are to enjoy equal rights and status.

Generally, retired EU migrants can be defined as EU nationals who have moved across national borders within the Union at some time and who are now regarded as retired in the sense that they are generally no longer formally engaged in paid work. The majority are reliant on various types of pensions and savings to meet their financial needs. Within this broad category it is important to make a further initial distinction between two separate groups. First, 'post retirement migrants' are those people who migrate to a second EU host country following retirement. A second group, 'returnees' are nationals of one EU member state who having previously migrated to another EU state(s) then return to their country of origin. The group labelled 'returnees' can itself be further differentiated into two groups: 'returning workers' and 'returning retirees.' 'Returning workers' are migrants who have returned to their country of origin after a period of work in another host member state, whilst, 'returning retirees' are those who return to their country of origin after a period of retirement in another EU member state. A more accurate label for those whose initial movement was motivated by the desire for work would be 'returning workers and 
their partners/spouses'. Many women included in this group did engage in paid labour whilst resident in a host state, indeed in a lot of cases it was imperative that they earned a wage. This group, however, also includes a number of women who were engaged in unpaid domestic/childcare work throughout their period of residence abroad. This type of differentiation within a generic category of retired EU migrants is important because the different groups outlined above are subject to different rules and regulations at both national and European levels, particularly in relation to social welfare provisions.

\section{The Legal Framework: Citizenship, Freedom of Movement and the Rights of Retired EU Migrants.}

European Citizenship, Rights to Residence and Social Rights.

Before looking more specifically at healthcare it is necessary to consider the rights conferred upon European citizens in primary and secondary legislation. The notion of European Citizenship is established in Article 17 EC (ex Article 8a) which states,

1. Citizenship of the Union is hereby established. Every person holding the nationality of a Member State shall be a citizen of the Union.

2. Citizens of the Union enjoy the rights conferred by this treaty and shall be subject to the duties imposed thereby.

The content and extent of these EU citizens' rights are laid out in Articles 17-21 EC (ex Articles 8a to 8d TEU). These rights can be summarised as follows: the right to move and reside freely in the EU, the right to vote and to be a candidate in both 
municipal and European level elections, the right (as necessary) to claim diplomatic protection under the authority of another Member State, and the right to petition the European Parliament. When considering this list of rights as the basis for a European notion of citizenship two points become immediately evident; their limited scope and the apparent lack of a social dimension. Indeed, Weiler (1998) has suggested that "the Citizenship Clause in the TEU is little more than a cynical exercise in public relations on the part of the High Contracting Parties noteworthy by what it does not do than what it does” (1998:10). Noting that none of the four rights listed above have yet been fully implemented, he moves on to assert that the most important right, i.e. the right to free movement and residence, is not granted according to an individual's status as a citizen "but in their capacity as factors of production” (Weiler, 1998 :13).

Within the EU a preoccupation with the mobility and residence rights of workers rather than citizens is hardly surprising given that the free movement of goods and labour lie at the heart of the European project. An interest in extending the right of residence to all its citizens is a much more recent concern. Article 8a section 1 of the Maastricht Treaty stated,

1. Every citizen of the Union shall have the right to move and reside freely within the territory of the Member States subject to the limitations and conditions laid down in this Treaty and by the measures adopted to give it effect. (bold as in text)

Similarly, the European Commission is keen to state that, "Subject to certain conditions (my italics) the extension of a right to residence to all EU member state nationals, was formally enshrined within the Maastricht Treaty (TEU)” (European 
Commission 1999 :2). In reality the measures and conditions referred to in the two preceding quotations serve to severely limit any substantive right to residence for those individuals who are not active in the paid labour market. To date migrant workers (and latterly dependant members of their families) enjoy superior rights of residence in comparison to those who are economically inactive ${ }^{\mathrm{i}}$.

Such differential rights to residence amongst various groups of European citizens assume further importance because they impact upon an individual's right to access social provisions when resident in a host state. As Ackers (1998) notes, the EU citizenship status proclaimed at Maastricht does not "confer a broad equality of condition as the concept suggests but simply a general and restricted right of residence” (pp. 110-111). Within European social policy it is often secondary legislative devices (i.e. Regulations and Directives) that define the access and scope of social rights available to nationals of member states of the EU in respect of their status as European citizens.

Whilst resident abroad migrant workers and their families are able to claim rights, including rights to healthcare and social provisions, under Directive 68/360 (OJ Sp. Ed. 1968, No. L. 257/13) on a parity with those nationals of the host state in which they are working. They gain access to their full rights as European citizens on the basis of their status as EU migrant workers. The right to residence of post retirement migrants, however, is based on a more general right of residence under either Directive 90/364 (OJ, 1990 L180/26) or Directive 90/365 (OJ 1990, L180/28), which is concerned with workers who have ceased their occupational activity. 
EU nationals wishing to take up residence on retirement in another member state in effect have no formal right to access the public welfare systems of the host state. For those people who have never worked in the host state the right to residence (or at least the social rights attaching to the right to residence), is highly contingent. In short they may be considered second or even third class European citizens (cf. Pollard and Ross, 1994). As economically inactive persons the right to residence of post retirement migrants is limited by two important conditions,

....[that they] are covered by sickness insurance...[and]....have sufficient resources to avoid becoming a burden on the social assistance system of the host Member State during their period of residence. (90/364 Article 1\{1\})

Resources are deemed to be sufficient if they are above the level of resources at which the host state grants the right of social assistance to its own nationals.

For (returning) retirees who wish to return to their country of origin after a period of retirement elsewhere in the EU the situation is further complicated by the fact that they may have to satisfy new requirements before being able to access social welfare once back home. In the UK for example, returning UK nationals may have to meet criteria laid down under the habitual residence test before having the right to access income related benefits such as housing benefit and income support (Eurolink Age, 1996). Recent reforms of this test (DSS, 1999) make it easier for returning EU retirees who are re-establishing links in the UK to access benefits. These reforms also provide an example of how European Law may influence social rights in a positive manner. The UK government reforms were in part a reaction to a recent European Court of 
Justice ruling (See case C-90/97 Swaddling v. Adjudication Officer, Judgement 25/2/99).

\section{Rights to Healthcare}

Rights to access public healthcare are an important component of social citizenship particularly for people of retirement age whose need for treatment and/or long-term care may increase with the ageing process. In the past the EU has been involved in coordinating cross national health campaigns and Article 152 EC (ex article 129) contains a declaration encouraging co-operation between member states on general health matters. In reality, however, the rights and entitlements vis a vis public healthcare are very much determined by national laws and the systems operating in individual member states (Hervey, 1998). In order to guarantee a right to residence in a host member state it has already been noted that retired EU migrants (with the possible exception of returnee workers) have to be covered by sickness insurance of some kind. Whilst some retired EU migrants may choose to purchase private insurance those with a residence permit may make use of any reciprocal arrangements that exist between EU member states in order to access public healthcare (Behzadi, 1994). Here the retired migrant is able to export their (national) right to healthcare (i.e. their public 'sickness insurance') as a national of a particular EU state and claim a similar right to public healthcare in the host state. Any costs incurred in their treatment abroad are then recoverable against their country of origin. These arrangements at European level are further complicated by various national laws and rulings which stipulate at nation state level the categories of persons covered by public healthcare and the costs, if any, to be incurred by the recipient (European Commission, 1997). The right to access public healthcare in another EU host state 
does not infer a right to the same standard or level of entitlement as previously enjoyed in the country of origin but (under the principle of non-discrimination) entitles the individual concerned to the same services as normally enjoyed by a national of the host state. This may be a factor in the decisions of some retired EU migrants to purchase private medical insurance for treatment abroad and it also appears to be the case that differing levels of public healthcare provision are an important factor in precipitating return migration to northern European member states.

The discussions above have sketched out the legal framework of European citizenship with regard to the residence rights retired EU migrants. The ways in which this effects their social rights and, briefly, the effect it has on their ability to access public healthcare in host member states have also been considered. Section 3 offers an outline of the methods used in the fieldwork from which the empirical findings of this paper are drawn.

\section{The Sample and Method}

Given that the fieldwork aimed to explore the respondents' own accounts and understandings of motivational factors and behaviour in relation to migratory movements in retirement, a purposive non random, sampling technique was adopted (Finch and Mason, Glaser and Strauss, 1970). This was part of a wider qualitative strategy (see Mason, 1994) that underpinned the study. Furthermore, the lack of coherent and reliable statistical data on international retirement migration (Williams, et al. 1997) ruled out the possibility of recruiting a representative sample. Practical 
considerations also had an influence in the choice of particular locations. It was important to seek out post retirement migrants, returning workers, and also a number returning retirees, and areas were chosen with this objective in mind. Ultimately, we were guided by the knowledge and investigations of the relevant researcher and the sample was drawn from the following locations:

- Greece: mainly Athens and the island of Corfu with a small number from Macedonia in northern Greece.

- Sweden: the whole country

- Italy: Trieste and the surrounding rural area, also around Lake Garda

- Portugal: Lisbon and the municipalities of Sintra and Caiscais which is an historic resort area south of Lisbon

- England: the whole country

- Ireland: Dublin and County Roscommon

Interviews were carried out these 6 different EU locations during 1998. In Greece, Sweden, Italy and Portugal four research partners were employed to conduct this task. A researcher based in Leeds conducted interviews in England and Ireland. A total 210 semi-structured qualitative interviews were held with retired EU migrants; 100 with post retirement migrants living in host EU countries and 110 with returnees who were resident in their country of origin. These interviews generated a total of 260 respondents who were either post retirement migrants (125) or returnees (135). It was originally intended that respondents be interviewed alone, however on a number of occasions couples were interviewed together. The gender profiles of the interviews is as follows: post retirement migrants: 33 males (interviewed alone) 42 females 
(interviewed alone), 25 couples (male/female); returnees, 43 males, 42 females and 25 couples. Interviews were conducted in the language most appropriate to the respondent, and were generally recorded on audio tape. Transcripts were then translated into English as necessary and interviews relayed by e-mail to the research fellow in Leeds where the data was systematically coded.

The texts were then analysed using basic grid analysis and thematic coding techniques. Overview grids (adapted from Knodel, 1993) provided a summary of the range of opinions (and the justifications for those views) across all the respondents, in relation to a specific question asked in the field. The development of these tables, and an accompanying percentage count of the respondents' various responses, provided an indication of the level of support for a particular view in terms of actual numbers of respondents. In this way the researcher was restrained from relaying an account based merely on the views of one or two particularly forceful, articulate respondents and/or a personal opinion on the matter under investigation. Overview grids also proved helpful in illuminating the full range of opinions offered.

In order to ensure that the thematic coding was systematic, consistent, and flexible the data was first coded according to a number of general relevant categories e.g. motivational factors in migration. Further investigation of the transcripts enabled the generation of further allowed sub categories (e.g. healthcare as a motivational factor) that more sensitively reflected the views of the respondents. The use of a Nud*ist software package allowed the data to be retrieved in any combination according to various base characteristics, specific questions and themes etc. In this way a rigorous and systematic analysis of the data generated was achieved. 


\section{Retired EU Migrants and Healthcare.}

Previous discussion has highlighted the limited extent to which the healthcare rights of retired EU migrant citizens are formally recognised in European legislation. The qualitative analysis presented below offers grounded insights into the ways in which the respondents seek to meet their healthcare needs. A privileged few are able to exclusively make use of private provision regardless of location, others at different times, either choose to, or have to rely on various rights to public healthcare linked to their status as national and/or European citizens. Decisions about accessing healthcare are not only influenced by a variation in the financial resources available to individuals, but also by disparities at the nation state level in the type and standard of public healthcare services provided in different EU countries.

Three Approaches to Accessing Healthcare.

Essentially the respondents divide into three groups when the issue of accessing healthcare is considered. The first and smallest group is made up of those respondents $[10 \%]^{\mathrm{ii}}$ who choose whenever possible to make use of private healthcare services wherever they find themselves located. A second larger group of respondents [24\%] also favour private health provisions following migration to a host EU country. This group, however, can be distinguished from the smaller group (who always choose private options) by the fact that significant numbers in this group are keen to retain rights to access public health and care services in their countries of origin. Finally, a group [41\%] of respondents stated that they ordinarily relied on publicly provided services whilst resident in other EU states. Approximately two thirds of this group also indicated that they relied on public health provisions in their country of origin. 
Choosing Private Healthcare: Money, Mobility and the Market Mentality.

A minority of respondents chose to opt out completely from the public healthcare rights available to them as either national or European citizens. Regardless of their location these individuals use their personal wealth to either directly purchase healthcare or pay into private medical insurance schemes. The Swedish returnee below clearly sees advantages in private healthcare over public provision,

"If you have enough money to pay for it, I think you'll actually get a better medical treatment abroad than in Sweden..... In Sweden, you have to wait a long time before you'll get treatment, and there's no freedom of choice.” R212

The following Dutch post retirement migrant (323) is similarly convinced that private healthcare insurance is the best way of ensuring that their personal medical needs are adequately met,

"after having studied the insurance alternatives in Portugal - many didn't accept us because of our age - we decided to keep our Dutch [private] health insurance, which is a lot better.” 323.

In terms of the location in which these respondents access healthcare, personal wealth has an important impact. The rich may choose to relocate to make use of particular doctors as they feel appropriate. Those reliant on individual insurance schemes may also choose a policy that enables them to return to their country of origin for treatment, or alternatively, they have may have the option of staying put and paying less for an enhanced service. In particular respondent [323] feels that he gets better value for money by remaining in Portugal and taking advantage of the comparatively cheap costs of private medicine, 
"......the insurance price is based on the Portuguese prices; in Holland the health services are much more expensive.” 323.

The rights to public healthcare that are an important component of social citizenship at both national and EU levels are of little concern to such respondents as they have the financial ability to exit from collective public welfare arrangements and access private welfare on an individual basis. In terms of healthcare, social citizenship only becomes relevant to such individuals when either their money runs out or an emergency forces them to engage temporarily with public services. It should be noted, however, that private arrangements, particularly those financed by individual insurance schemes, are often of limited use in cases when the need for long-term care becomes a reality. Older people who suffer from progressive chronic diseases associated with the ageing process that require high levels of often expensive nursing care regularly find themselves excluded from private insurance schemes. Apart from the very rich many will find that ultimately they have little choice but to rely on public healthcare systems backed up if they are lucky by familial care.

A Public/Private Mix: Making Choices, Maximising Benefits.

A second, larger, group of respondents [24\%] stated that they made use of private health services whilst residing abroad. Within the study this group is largely made up of migrants from the northern European countries of Sweden, Germany and the UK, who had chosen to retire to Southern European locations e.g. Spain, Portugal, Greece, Italy. This mirrors a more general pattern in post retirement migration in Europe in that such migration is generally northern Europeans migrating south (cf. King et al, 2000, 1998; Warnes et al, 1999; Williams et al, 1997); a movement that reflects their 
level of material advantage and regional inequalities across Europe. Concerns about poor levels of public provision often prompt such migrants to take out private medical insurance and/or, pay privately for minor treatments in order to overcome any perceived deficiencies in their host state's healthcare services. These comments from a German couple illustrate this approach,

$X$ - “A prejudice exists about Italy’s medical system being very bad. A dear friend of ours who died three years ago in Vienna - he didn't trust hospitals here at all... [interrupted by wife]

$Y$ - I've heard from some friends - some Italian friends - that the hospital in Salò is not that good, but when I went to the dentist here in Gargnano I had a fairly good experience. Moreover there's a GP and we've always been quite satisfied....it's just hospitals that seem to be quite bad - I wouldn't like to go to Salò

$X$ - The widespread belief among Germans residing here is that, if you need to go to hospital, you'd better run away from here. They usually go to Bolzano, to Innsbruck or to anywhere in Germany.

Y - I always go to doctors privately [in Italy] and I don't need to see them that often but all the experiences I had weren't bad.” 122/123.

Similarly a Swedish returnee who had lived in Spain noted, It wasn't at all problematic, getting ill in Tenerife, because all the Swedish people had great health insurance. Because of this, they got an excellent care. Actually, I think they got better [private] care in Spain [In comparison to Swedish public provision] you don't have to share a room. But this was only 
because of the insurance. The public healthcare in Spain is awfully bad. You really need to have a private insurance." $R 209$

In the past for some respondents who retired abroad the decision to take out private health insurance was of course not simply a matter of choice but rather necessity. For example, an English returnee whose husband was the driving force behind a decision to retire to Spain (in spite of a past history of health problems) stated,

"I realised too with the health service, what the pitfalls would be, I was well aware that there was no reciprocity at that point. I don't think so anyway. We were very involved when we went there with private health insurance. We just had private medical insurance in Spain, because we knew that when we came back we would be on the national health.... one of the pitfalls was that you had to buy yourself in [to private insurance schemes] at some colossal cost.” R015

The above quotation serves to highlight two important issues in relation to debates about national and European social citizenship. First, the importance of the reciprocal agreements that now exist between member states to ensure that EU retired migrants who are resident in another member state have the right to access the public healthcare systems available in their host country. Today respondent R015 and her husband would (if they so wished), be able to access Spanish public healthcare provisions in the event of illness abroad (King et al.,2000; Cahill, 1999); although they still retain the choice as private consumers to opt out of Spanish state provisions by purchasing healthcare. The important point to stress is that they would now have a right, effectively as European citizens, to call upon public health services to meet their needs wherever they reside within the EU. It should be noted, however, that these 
European rights are based on a principle of non discrimination rather than harmonisation (i.e. that individuals have a right to the level of health service provided in the host country) and certain needs may still be ignored. When considering the healthcare rights of EU retired migrants the notion of European social citizenship delivers new rights in a very real manner. National rights that were once limited in their effect to the borders of a particular nation-state have become the basis for a second level of social rights that operate beyond national boundaries.

The second significant point to note is the comment "....that we knew that when we came back we would be on the national health." Interestingly over half of the respondents who stated that they used private health services whilst resident abroad also actually made use of, and/or were keen to keen to retain, any rights to public healthcare in the nations that they have left behind. They do this by returning temporarily, or sometimes permanently, to their country of origin to access treatment or care available to them because they are able to officially satisfy conditions of nationality or residence as laid down by individual nation states. For example, this British woman who originally 'retired' to Spain made regular trips back to England for NHS medicines,

"I used to come back three or four times a year to collect my prescription. And I carried a slip of paper, authorisation to get me through customs, and then I would have three months supply.” R019

Similarly, this retired migrant who lived in Portugal made sure that she retained residency status in Belgium in order to maintain access to public healthcare. 
"We do not have very good experiences in the hospitals, for instance. This is one of the problems We have here a very good doctor who is Dutch, but I always think if I lose her what am I going to do, I very much dislike the hospitals here........the system doesn't satisfy me I feel insecure........We should be allowed to choose our own doctors wherever we are and the costs should be fully covered [reimbursed] by our national systems"

[This medical doctor is a private one. The respondent is officially living in Belgium so that they can access healthcare there. She goes back to Belgium twice a year to have her preventive exams for cancer.] 303.

These respondents are continuing to make pragmatic use of their status as citizens and/or residents of a particular nation state in order to claim rights to public health services, rather than exercising any rights they may have at a European level. Returnees permanently relocate back to their country of origin in order to do this, whilst some retired migrants who are effectively resident abroad appear to work the system to their own advantage, by retaining an address or property in their country of origin. Within our study for example, 36 respondents (including 20 post retirement retirees, 16 returnees) identified themselves as 'seasonal migrants' who divided their time between two countries. These were northern Europeans who maintained homes in two or more locations, although a limited number also made use of links with family members who were resident elsewhere.

At risk of stating the obvious the study appears to confirm that this trend (to retain healthcare rights in the country of origin) is closely linked to perceptions about the extent, quality and (lack of) financial costs of particular European nations' public 
healthcare and welfare systems. After all when concerns about public healthcare provisions are significant it is counterproductive to physically relocate in order to exercise the right to access another system of public welfare which results in poorer quality healthcare and/or increased costs. An analysis of the interviews conducted with Swedish and British returnees, countries whose citizens enjoy rights to extensive, often 'free' (or highly state subsidised) public health and care services, reveals that an entitlement to public health provisions was an important factor in many decisions to return 'home' on a permanent basis. In 33 out of 40 interviews conducted with Swedish and British returnees respondents stated that failing health and the better capability of their home country's public welfare system to meet needs was an important factor in their decision to return. These respondents widely believed that the public systems, which they retained the right to access on return, could more adequately meet their increasing/changing healthcare needs than the services that they relied upon in their host states.

The steps that a British returnee (previously resident in Greece) took to ensure access to the NHS serve to illustrate this,

"One thing was my wife's health - her arthritis improved greatly because of the sun and the dry climate but it started getting worse again, and we realised we wouldn't be able to afford the proper treatment for it in Greece....... At first we weren't sure what we were going to do, because the first stage was to get a doctor and decide what had to be done, so we had to re-establish ourselves with an address in England so we could then become recognised by the NHS, so we went to live with my step-daughter in Bristol, and we wrote to everybody and 
said, this is where we live, we are back, here we are officially, we are now English residents.” R017

Similarly, as respondent R204 indicates below whilst, many of the Swedish returnees chose to pay for private health insurance when abroad. They were also worried about increasing age bringing about failing health and the possible need for some form of long-term care or permanent medical assistance for chronic conditions in the future. As the risk of needing long-term care or frequent medical intervention increases then so the importance of being able to access public provisions assumes a greater importance and is a significant factor in precipitating a return to a setting (usually the country of origin) where such services are seen as being available.

"When we moved to Spain, we were recommended to take health insurance. Therefore, we took out insurance with the biggest company in Spain and we never had any problems...... The insurance company paid it all and the doctors were great. We had absolutely nothing to complain about..........."

[Later in the interview.]

"Well, it was because of my husband, he couldn't manage to live in Spain without any help from friends or otherwise, he would have to pay for care. When we moved down to Spain, we were rather young compared to the others; sometimes the difference in age was at least twenty years. Therefore, we noticed what happened to others when they got old. Maybe they had to undergo an operation, and after some time in hospital they had to go back home. At the private hospitals, there were no rehabilitation centres. I remember some particularly good friends of ours. They had to pay all the care at home, and it 
cost the earth.......The last years in Spain, my husband needed a lot of help. He wasn't able to drive any longer, and he had such a terrible pain.” R204.

For northern Europeans who have chosen to access private healthcare whilst resident in southern Europe the continued ability to access a range of quality public healthcare services (and in some cases family support) in their country of origin is clearly an important contributory factor in many later return permanent return migrations. The opportunity to later drop individually purchased private healthcare arrangements in a host country and advantageously move back into collectively organised public healthcare (through return migration) is available exclusively to those migrants who meet two important criteria. First, on retirement they have to move to a country which offers a level of public healthcare service below that of the system that they have exited; this enables them to secure some advantage when they eventually choosing to return to their first location. Second, they have to be able to afford the cost of private treatments or insurance cover in their chosen host country. Within the context of this study, generally though not exclusively, this translates into a situation in which the wealthy nationals of northern European states are able to retire to southern EU member states in the comfortable knowledge that an extensive range of publicly provided services exists elsewhere for them to fall back on as and when the need arises. To this extent those who have the material and practical capability to move in and out of public healthcare arrangements in this way may be regarded as privileged citizens in relation to other respondents in the study.

\section{Reliant on Rights: Using Public Healthcare}


A third group of respondents within the study indicated that they were (or had been) to a large extent reliant on public healthcare provisions in host states with two thirds of this group also stating that they were dependant on public healthcare provisions in their country of origin. When resident in host countries these respondents effectively rely upon their rights as European citizens to guarantee them access to the publicly provided treatment and care that they require. There are very few respondents of northern European origin in this group. Typically those who migrate from the north to the south of Europe without access to private health services return permanently to their country of origin in order to make use of what they regard to be better public healthcare services. This is particularly true in the case of long-term or serious illness, as far as the respondent R001 is concerned the Portuguese retirement dream soon turned into a nightmare largely because of inadequate public healthcare. The only viable solution he could see was a return to England as soon as possible in order to ensure adequate public healthcare provision for his wife.

"I was perfectly happy, she was a bit dubious at first, but then [she] settled in, and then she started to feel ill just towards the end, complaining of the cold all the time, but that was because, as we found out later, that her kidneys were failing..........We went to a local Portuguese doctor, er...she detected high blood pressure and put her on tablets for that, but they didn't investigate beyond that. It was only when we got back here that they did blood test and immediately took her in and gave her a transfusion.

\section{Q: SO YOU CAME BACK IN ORDER TO HAVE HER DIAGNOSED?}

Yes, I mean the medical service there is extremely poor, very poor...If you go to a doctor you've got to look for a foreign doctor who speaks English.....and then, 
you see well you've got to pay anyway, and you get some of it back through the Portuguese system, and we only got into that system just before we left, it took five years to get into it...er but to see one of their national health service doctors is very difficult

\section{Q: SO ALL IN ALL, HOW WOULD YOU ASSESS THE SERVICES?}

They're just not available, to any degree...if you go into a medical scheme, which was my intention actually, but it didn't work out, you'd probably get the service, but then the hospitals are very poor, I mean I had a neighbour, an Englishman, who lived about a mile away, he was taken ill, so we took him into Faro hospital, and went into see him, and he was on a trolley in the corridor, a very narrow trolley as well, they had to strap him on to keep him on it and he was facing the pipes at the end of the corridor and we said to him can't you turn him round so at least he can see. He was on that trolley ten days before he died, he never got into a ward, and he died of bleeding ulcers, pneumonia, and something else, I cant remember.

\section{Q: HE WAS A FRIEND}

Yes. I mean these are the sorts of things you see around you, I mean he wasn't in any private scheme, and so he went in to the local hospital and that was the result - there just weren't any beds. Had he gone in the winter he may have got a bed, but some other cases, tourists as well you see. We couldn't have stayed there. There is a dialysis unit in Tavira now, I believe, but I didn't know of its existence then, but having once been diagnosed here there was no way I could take her back there knowing the system was so appalling..... 
Q: AND YOUR WIFE IS AVAILING HERSELF OF THE NATIONAL HEALTH SERVICE HERE?

"Yes, I mean she has to, its costing something like £25,000 a year her treatment.” R001.

For northern Europeans the right to access public healthcare services in their country of origin in order to meet any increasing needs due to ageing or serious illness appears to be a major factor in precipitating movement amongst this group.

So far discussion has focused on northern Europeans and the impact that healthcare systems have on their decisions to return home. A consideration of the data generated by those respondents within the study originally resident in southern European states (i.e. returnees from Italy, Portugal, Greece) highlights four important issues relevant to this discussion of healthcare rights and citizenship. The first point to note is the almost total absence of privately purchased provision amongst these returning southern European respondents. There are only two instances when such respondents (Italian interviews; R107/8, R121/L110) mention making use of private hospitals in host states. This is of course not surprising given that the principle motivating factor behind the initial movement of Southern European respondents was the search for work abroad (usually in more prosperous northern European states), often to escape poverty at home. For example,

"I would never have left if it wasn't for the money. When I left [Portugal] I made PTE 10,000 per hour. There [France] I earned PTE 100,000 per hour.” R304. 
"There was poverty...we had just bought the tractor and we were in debt, we had just sold our tobacco crop and yet we were still in debt. We could not make ends meet our children were small, 4, 6 and 8, we were in need, we had to take care of them. My husband left first and then I followed...... as did everyone else.” R409.

Making use of private healthcare provisions on return to their country of origin is also rare amongst the southern European returnees interviewed. The few that do regularly use private healthcare cite deficiencies in the available public healthcare systems as the main reason for their decisions to use private services. For example,

"I regret that here I don't have the same medical assistance that I used to have in France because in Portugal [public] healthcare is very bad.........In Portugal, healthcare works really badly. I had to turn to my private doctor... but my health didn't improve."

[She speaks about the seriousness of her conditions (cataracts and diabetes) and about the difficulty of being assisted here in Portugal. She explains that going to her doctor is expensive because she has to pay for the appointment, the medicines and also the taxi-cab.] R313.

Second, with the exception of the few respondents noted above the vast majority of southern European respondents are reliant on their rights to public healthcare both when resident abroad and on return to their country of origin. During their time in host countries as migrant workers many were able under European legislation to claim access to public healthcare for both themselves and their family on a parity with the nationals of their host state. However such rights to healthcare are dependant on an individual's status as an EU national migrant worker rather than on nationality. As 
this Italian returnee notes, in the past these arrangements seriously limited his right to public healthcare when he returned temporarily back to Italy.

"Well, first of all let me say that the Luxembourg NHS is very good. Everything was free, but, and there is a but. One was entitled to free services as long as one worked there. When we finished working in December, we lost any rights to be treated in Luxembourg, but, at the same time we didn't have any rights to be treated in Italy because we were regarded as migrants residing abroad - the result being that, for 4 months a year, we weren't entitled to medical assistance anywhere. If you needed hospital treatment you had to pay for it. Then, every time we went back to Luxembourg, we had to apply for free medical assistance again.” R116.

Third, a recurrent perception amongst southern European returnees is the lack of quality in public healthcare services in their country of origin in comparison to those they experienced in host countries in northern Europe. The prevalence of this view varied according to the state under discussion. Italian returnees on the whole were satisfied with the Italian public healthcare system, although one respondent was critical of the bureaucracy involved and another saw the German system as superior. Many Portuguese (c.f. R313 above) and Greek returnees, however, regarded the treatment and coverage that they received in public systems as migrant workers abroad as superior to that which they now have access to 'at home.' Two women were particularly frank in highlighting some of the shortcomings of Greek public healthcare,

"The most important thing that Germany offered to us was the medical care. I learned there to visit my doctor and have a check-up regularly, I always had all 
the examinations done in the same day..... There is a big difference between here and there. In Germany I was led from one doctor to the other, they would listen to me, give me a handshake, here nobody cares. Fortunately my brother is a doctor and I consult him and my son-in-law is a nurse and they help me otherwise I would have to wait at the IKA services."

[Later in the interview.]

"Greece is good but there is no organisation............. had to have thyroid surgery here in Greece and I wouldn't have got a bed in the hospital if my brother hadn't seen a friend of his and secretly given him extra pay. I didn't like that...I was offended...what if you don't have somebody? Will you be left to die?...The woman next to me had been waiting for 50 days to be accepted...... also there is a big difference in cleanliness, in order, in the medical care. The nurses in Germany would smile at you, would comb you, would hug you. When I speak about this, they reproach me that I keep talking about Germany...but this is the truth even if it hurts. I love my country that's why I am bitter about it." $R 412$

“......here one has to secretly give doctors extra pay to have oneself looked after. You have to wait for hours in the medical services of IKA to be examined by the doctors and nobody gives a damn." R413

Fourth, in contrast to their northern European counterparts, concerns about health in general and more particularly accessing public healthcare play only a minor role in precipitating the return movements of southern European respondents (returnees). Reasons given for return to country of origin by southern European returnees were 
usually linked to periods of paid employment ending (due to redundancy or retirement) or a desire to return home for some kind of family reason. Typically, this was either be to provide informal domestic care for an ageing parent and/or a wish to be near relatives in the homeland (See Ackers and Dwyer, forthcoming and cf King, 1994). On several occasions the onset of poor health or disability (sometimes due to dangerous working conditions and accidents) did force a small number of migrants to return to their country of origin earlier than anticipated. A small number were also similarly advised to return to a warmer climate for health reasons.

Although in reality permanently resident in their country of origin at the time of interview a small number of southern European returnees were also keen to work the system in order to continue to access the public healthcare provisions of their previous host country.

"I have medical care here but officially I do not appear as a permanent resident in Greece. I haven't transferred my rights from Germany as I have already said, my children live in Germany so officially I appear as living with them there. Sometimes I go and visit them for a couple of months and then I come back again, and as far as doctors are concerned, when I return from Germany I get a document which entitles me to medical care here. I also have the IKA insurance but I don't use it, I go to Germany for my check-ups. I have been doing this for 13 years now. I got my pension when I was 60 years old and now I am 73. I get my pension is paid in my bank account in Germany; when I come back in Greece I bring a big amount of money with me to live on.” R416.

Similarly, this Portuguese couple keep their residency status in France, 
“........because I have a daughter there and if something happens we have somewhere to stay. But I don't have any intention of going back there [permanently]. If I have worked there and if I have been deducted there [i.e. paid contributions] then it's logical that if I have healthcare needs that I will use the French health services"

In the past he has used free French public healthcare in order to get quick treatment, and they in intend to use it in the future,

“...... here [Portugal] we need to wait 4 to 6 months for a consultation or an operation. In France, it's not like that..........A small tumour appeared in my eye. I was called one afternoon and the following day I was operated on.”

"If we need something, an operation for example, we prefer to do it in France than in Portugal and wait 6 or 7 months.” [Wife's addition.] R308.

Whilst this practice was not as widespread as amongst northern European respondents it more generally emphasises the point that some retired EU migrants are not adverse to claiming false residency if such claims bring with them the right to access more comprehensive public healthcare systems. The two returnees quoted above continue to make use of family links in past host locations in order to access better the public health systems.

\section{Conclusions. European Social Citizenship: A Substantive Reality?}

In a strict legal sense the right to access public healthcare within individual EU nation states often has very little to do with citizenship or indeed nationality. In many cases (though not exclusively) the right to healthcare is linked specifically to legal residency 
status within a particular EU country (European Commission, 1997; Gardner [ed.] 1994). A considerable number of the retired EU migrants within this study appreciate the importance of the residency issue. Many returning retirees decide to return to reside permanently in their country of origin if they believe such a move will secure for them some advantage in terms of public healthcare provision. Certain other respondents whether they are (northern European) post retirement migrants or (southern European) returnee workers are willing to retain formal residency status in northern EU member states in which to all intents and purposes they are no longer resident in order to gain access to what they perceive to be better public healthcare provisions. Whilst this approach to accessing healthcare rights should perhaps not be applauded it is nonetheless understandable. It is one consequence of the varying levels of entitlement, quality and patient costs that are available to retired EU migrants in the different national healthcare systems of EU member states. It is not the intention of this paper to set up a hierarchy of public healthcare systems and criticise the arrangements of individual EU member states as inferior or lacking. Such an approach is not only unhelpful but also fails to take into account that many national health systems in southern Europe were established in the late 1970's and early 1980's (see Freeman, 1999 :82). However, for as long as real, or perceived, differences exist to convince retired EU migrants that the public healthcare systems of southern European member states are inferior to their northern European counterparts in meeting their needs we should not be surprised if individuals strategically choose to secure the best deal for themselves any way they can.

Such tactics are even more understandable given the limits and tensions at the very heart of the EU. Rhetorically the EU is committed to reducing social exclusion across 
Europe but simultaneously it continues to endorse an exclusive notion of citizenship. Formally Article 17 EC (ex Article 8 [the establishment of citizenship]) and Article 12 EC (ex Article 6 [non discrimination on grounds of nationality]) combine to declare a common status of European citizenship, however, that status is differentiated with essentially only EU migrant workers enjoying the same social rights as host country nationals. If European social citizenship is to become a substantive reality for retired EU migrants then the right to healthcare should cease to be contingent on any conditions laid down in Directive 90/364 and elsewhere. The dilemma facing the EU centres around the kind of citizenship it wishes to promote in the future.

Fries and Shaw (1998) argue that a recent ECJ judgement may indicate a general right to social welfare for all EU migrants (which is derived directly from their status as citizens of the EU) whether or not they are economically active. In Case C-85/96 (Martinez Sala v. Freistaat Bayern, judgement on 12 May 1998) the ECJ overturned a previous decision by the German courts and found that Martinez Sala (a Spanish national resident in Germany from 1968 and reliant on social welfare benefits from 1986 onwards), had an entitlement to a child raising allowance for her new daughter. It remains to be seen if this judgement marks a significant step towards the development of a European Citizenship that grants equal status in respect of social rights to all EU citizens (see Ackers, 1998). If the EU is serious about European citizenship it needs to address discriminatory elements of its own legislation to ensure that individuals outside the paid labour market (including retired EU migrants) are not systematically denied their full rights as citizens.

\section{Bibliography.}


Ackers, L. and Dwyer, P. (forthcoming 2001) Senior Citizenship? Retirement, Mobility and Welfare in the EU, Bristol, Policy Press.

Ackers, L. (1998) Shifting Spaces: Women, Citizenship and Migration Within the European Union, London, Policy Press.

Age Concern (1996) Retiring Abroad: Information for Older People Planning to Leave the UK, London, Age Concern.

Behzadi, S. (1994) ‘Hallmarks of Citizenship’ in Gardner, J. P.(1994) [ed.] op cit.

Cahill, M. (1999) 'British expatriates' experiences of health and social services on the Costa Del Sol', in Athias, F. and Lazaridis, G, [eds.] (1999) Into the Margins: Migration and Social Exclusion in Southern Europe, Aldershot, Avebury.

DSS (1999) 'Habitual Residence Test Reforms Provide Fairer Access to Income related Social Security Benefits,' Press Release 99/132, 14th June 1999, London, Department of Social Security.

European Commission (1999) Report from the Commission to the Council and European Parliament on the Implementation of Directives 90/364, 90/365 and 93/96 (Right of Residence), Brussels, European Commission. 
European Commission (1997) Missoc-Social Protection in the Member States of the European Union, Luxembourg, Office for the Publications of the European Communities.

Eurolink Age (1996) Position Paper on the Free Movement of Older People Within the EU, London, Eurolink Age.

Freeman, R. (1999) 'Institutions, States and Cultures: Health Policy and Politics in Europe,' Chapter 5 in Clasen, J. (1999) [ed.] Comparative Social Policy: Concepts, Theories and Methods, Oxford, Blackwell Publishers Limited.

Finch, J. and Mason, J. (1990) 'Decision taking in the fieldwork process: theoretical sampling and collaborative working', pp. 25 -50 in Burgess, R. G. [ed.] (1990) Studies in Qualitative Methodology, Volume 2, London, JAI Press.

Fries, S. and Shaw, J. (1998) 'Citizenship of the Union: First Steps in the European Court of Justice,' European Public Law, vol. 4 issue 4 December 1998.

Gardner, J. P. (1994) [ed.] Hallmarks of Citizenship: A Green Paper, London, The British Institute of International and Comparative Law.

Glaser, B. G. and Strauss, A. L. (1970) 'Theoretical sampling’, in Denzin, N. K. [ed.] (1970) Sociological methods: A source book, London: Butterworths.

Hervey, T. (1998) European Social Law and Policy, London, Longman. 
King, R. (1994) 'Migration and the single market for labour: an issue in regional Development', in Blacksell, M. and Williams, A. M. (1994) [eds.] The European challenge: Geography and development in the European Community, Oxford, Oxford University Press.

King, R., Warnes, A. M., and Williams, A. M. (2000) Sunset Lives: British Retirement Migration to the Mediterranean, Oxford, Berg.

King, R., Warnes, A. M., and Williams, A. M. (1998) 'International retirement migration in Europe’, International Journal of Population Geography, 4, :91-111.

Knodel, J. (1993) 'The design and analysis of focus groups: a practical guide', in Morgan, D. L. [ed.] (1993) Successful focus groups, advancing the state of the art, London: Sage.

Levitas, R. (1998) The Inclusive Society? Social Exclusion and New Labour, Basingstoke, Macmillan Press Limited.

Mason, J. (1996) Qualitative researching, London: Sage.

Pollard, D and Ross, M. (1994) European Community Law. Texts and Materials, London. Butterworths. 
Warnes, A. M., King, R., Williams, A. M. and Patterson, G. (1999) 'The well being of expatriate retirees in southern Europe, Ageing and Society, 19 :717-740.

Weiler, J. (1998) 'European Citizenship, Identity and Differentity,' Introduction in La Torre, M. (1998) [ed.] European Citizenship an Institutional Challenge, The Hague, Kluver Law International.

Williams, A. M., King, R. and Warnes, T. (1997) 'A place in the sun: international retirement migration from northern to southern Europe', European Urban and Regional Studies, vol 4 no 2 pp115-134.

\section{Acknowledgements}

I would like to thank the partners and respondents who took part in the research. Also thanks to Louise Ackers, Kirk Mann and two anonymous referees for their comments on a previous draft of this article. This paper is part of a research project funded by the Wellcome Trust under grant number 048853.

\footnotetext{
${ }^{\mathrm{i}}$ The negative implications, particularly for women, of attaching rights to an individual's status as a European worker rather than a citizen has been commented on elsewhere. Levitas (1998) notes an 'endemic' preoccupation with paid work in the legal and financial framework of the EU that fails to take into account the unpaid domestic labour of many women. Whilst legal definitions of European citizenship remain centred on paid work alone the rights of many EU migrant women will remain marginalised (Ackers, 1998)

ii add here
} 